\title{
The Prayuth Regime: Embedded Military and Hierarchical Capitalism in Thailand
}

\section{Prajak Kongkirati' and Veerayooth Kanchoochat ${ }^{2}$}

\begin{abstract}
This paper explores the Prayuth regime, which began with a military coup in May 2014. Politically, we indicate how the junta has embedded its power in ways different from the past. It does not pursue a power-sharing governance as in the Prem and Surayud governments, but tries to militarise the cabinet, parliament, and even state-owned enterprises. The new constitution is designed to institutionalise the power of the military and the traditional elite vis-à-vis the electoral forces. Ironically, however, the junta's rule by military decree and discretionary power have weakened the bureaucratic polity, rather than strengthening it. Economically, the Prayuth regime forms a partnership with a group of Sino-Thai conglomerates to establish the Pracharath scheme, with an aim to differentiate its grass-roots development policy from Thaksin's populism (Prachaniyom). Nonetheless, it has become a platform through which the giant firms perform the leading role of 'Big Brother' in supervising small businesses in their sectors. Pracharath therefore reflects the collective endeavours of the conglomerates to replace competitive markets with hierarchy, rather than encouraging local firms to catch-up with them.
\end{abstract}

KEYWORDS: Thai Politics, Military, Prayuth Government, Pracharath, Thai Economy, Hierarchical Capitalism

\section{The Prayuth Regime: State, Society and Business}

$\mathrm{O}$ 22 May 2014, the military junta, under the name National Council for Peace and Order (NCPO), led by General Prayuth Chan-ocha (henceforth Prayuth) assumed power after staging a coup that toppled the elected government of Yingluck Shinawatra, sister of former prime minister Thaksin Shinawatra. Its leader Prayuth was appointed by the coup-installed assembly to serve as the country's new Prime Minister. He brought back military rule, whereby the military has dominated Thai politics under the auspices of the monarchy. Under repressive military rule, civil liberties are restricted, free speech is censored, criticism is prosecuted and political activity is prohibited. Since the coup, the generals have established themselves as the new ruling elites by enhancing their status, scope of power, budgets and manpower. They also seek

\footnotetext{
${ }^{1}$ Faculty of Political Science, Thammasat University, Thailand; prajakk@yahoo.com.

${ }^{2}$ National Graduate Institute for Policy Studies (GRIPS), Japan; veerayooth.k@gmail.com.
} 
to maintain their dominance through constitutional design by weakening the majoritarian democracy and undermining the influence of political parties and civil society.

As of mid-2017, Thailand remains the only country governed by direct military rule. Prayuth's coup-installed government is the longest-serving military authoritarian government the country has ever witnessed since the 1950s. Although the commonly used concepts like 'network monarchy' (McCargo 2005) and 'deep state' (Merieau 2016) can demonstrate the political struggle underpinning the two recent coups, they are inadequate for explaining this newly established regime. In this paper, we make one of the earliest attempts to propose a new framework to understand the 2014 coup and its installed regime by investigating the changing political structure, power relations and roles of the military in relation to other social forces. The paper is divided into two main parts: a) state-society relations, investigating the new political structure and power relations created by the military at the centre of polity, and; b) statebusiness relations, exploring the realignment between the junta and Sino-Thai conglomerates and their collective attempt to create a new mode of economic participation.

\section{State-Society Relations: Embedded Military and the Transition to Military-Guided Semi-Authoritarianism}

According to the comparative politics literature, military rule was the most common form of non-democratic regime in modern times (Brooker 2009: 81). Between the end of WWII and the beginning of the third wave of democratisation, the military had intervened in approximately two-thirds of the more than 100 non-Western states. In the later 1970s, the military controlled the government in about one-third of these countries (Nordlinger 1977: 6). However, after the Cold War, military coups and military governments gradually disappeared and became anachronistic. Only a few poverty-stricken countries still encounter political intervention by the army or military coups. Thailand is the most economically developed country among the countries in the post-Cold War era in which military coups have been successfully staged. Moreover, since the late 1990s, Thailand is the only country, except for Burkina Faso, in which elected governments were overthrown by direct military coups twice in less than a decade (see Marshall and Marshall 2015). ${ }^{3}$

Fundamentally, the 2014 coup is a continuation of the previous coup that occurred in 2006, and the 2017 junta-backed constitution is a repeated effort by the Thai establishment to maintain their political dominance under the

\footnotetext{
${ }^{3}$ Also see Powell, Jonathan and Clayton Thyne, "Coups d'etat, 1950 to Present" dataset. Available at http://www.uky.edu/ clthyn2/coup_data/home.htm (accessed 2 June 2017).
} 
guise of constitutional rule. To understand the army leaders' political vision, one needs to discern Thailand's socio-political context since 2006. The military has stepped in to protect its own power and interests because of three main factors that they perceive as threats capable of destabilizing the old hierarchical political structure. First and foremost, the process and consequences of a delicate royal succession that might affect the privilege and power of the royalist elites, including the military. The looming succession was a fragile and historic moment that brought anxiety to the established elites. Second, the strong political parties with a solid mass-based support among rural voters and urban working force of the Thaksin camp that have been invincible at the ballot-boxes since the 2001 elections. Lastly, the birth of mass politics based upon ideological and political interests, which produced the endless occurrence of turbulent and violent extra-parliamentary activism by color-coded movements. These three factors combined are the reasons that forced the military to reassert their own position and influence.

Against this background, the army feels it imperative to control the 'transition' (i.e. succession), a term they have often repeated. Junta chief Prayuth has repeatedly stated in public that the army needs at least five more years in power to steer the country out of crisis (Matichon 24 April 2016). The military fear a power vacuum in this fragile time and believe that only their institution can ensure the stability and interests of the royal-military elites. Elected politicians and mass movement need to be subdued so that they no longer pose a significant threat to the old establishment. The military's overarching plan is to reorder the political structure that keeps the power and status of traditional elites intact. They attempt to do this while maintaining a façade of democracy to gain a certain degree of legitimacy from domestic groups and the international community.

\section{A Return to Premocracy?}

Several observers, both Thai and foreigners, opine that the junta would take Thailand back to the 'semi-democracy' regime witnessed in the 1980s during the premiership of Prem Tinsulanond (March 1980 to April 1988), or 'Premocracy' (e.g. Thitinan 2016; Thai Rath 30 March 2016). However, we argue that this observation is inaccurate and contains some false comparisons that prevent a full understanding of the current ruling junta's political vision.

The 'semi-democratic system' was a product of the 1978 constitution, in which elected and unelected power holders coexisted side by side in the assembly and government. The 1978 constitution allowed unelected prime ministership, and established a bicameral National Assembly, consisting of an elected House of Representatives and an appointed Senate. The senate-by-appointment and unelected premier were mechanisms to retain power bases for the military and traditional elites within the parliamentary system in the 1980s. These two old mechanisms were revived in the 2017 charter. However, the power-sharing 
mode of the 1978 constitution reflected the army's willingness to compromise and adapt to the changing political environment, which saw the rise of business classes who demanded participation in state affairs. The 2017 constitution, on the contrary, demonstrates the recalcitrance of the army to adapt to the new political landscape transpired in Thai society since the early 2000 s.

Instead of pursuing a power-sharing model like in the Prem era, the current ruling junta led by Prayuth and General Prawit Wongsuwan aims to consolidate and entrench military power in the political system for the long term. They aim to re-centralise the state structure by increasing the duties and scope of power of the military at the expense of civil society and elected local administration. The new political structure is designed to control majoritarian democracy by blunting the power of political parties. The 2017 charter, drafted by a commission led by Meechai Ruchupan, established a bicameral National Assembly, consisting of an elected House of Representatives (500) and an appointed Senate (250). The Lower House's term is four years, while the senate lasts for five years. In the first five years, the NCPO has the authority to handpick a 250-member Senate, with six seats reserved for the security forces - army, navy, defence, police, supreme commander, and defence ministry permanent secretary. ${ }^{4}$ The NCPO leaders claim that the appointed senate will carry out their '20-year national reform strategic plan', and also argue that the incorporation of the security forces into the senate will prevent military coup attempts (Khaosod 17 March 2016). ${ }^{5}$

Besides the junta-appointed senate, many empowered independent organisations (election commission, constitutional court, anti-corruption commission, ombudsman, etc.) will function as veto mechanisms that can check and disqualify the elected government. It is important to note that all these independent organisations did not exist in the Prem era. Under the 1980s'semi-democratic period, the elected government was short-lived because of its weakness and internal conflict within the coalition. In the past decade, these independent organisations became powerful actors that can paralyse or even bring down a popularly elected administration as we have witnessed since 2006.

Another significant institutional mechanism created to weaken majoritarian democracy is the newly designed electoral system. Meechai's commission changed the electoral system, from a mixed-member majoritarian system (MMM) with 375 single-seat constituencies and 125 party list seats, to a socalled mixed-member apportionment system (MMA). Under the MMA

\footnotetext{
${ }^{4}$ After five years, the senate will be appointed by a selection committee comprised of nominated professional groups.

${ }^{5}$ According to the original draft, the senate could not vote to select the prime minister. However, the NCPO inserted a second referendum question at the last minute, asking voters to decide if the Senate should have the power to select the premier in a joint-session with the Lower House. In the referendum, the majority of voters approved the senate's power to select the premier. This paves the way for a potential non-elected MP premier, most likely junta generals or their nominees.
} 
system, there are 350 constituency seats and 150 party list seats. Instead of casting two separate votes (one for a candidate and one for a party list), under the new system voters can cast only one vote and that vote will count as both a vote for the chosen candidate and for that candidate's party for the party list seats calculation. The total share of seats of any party is determined by the total number of votes that party receives nationwide via the constituency vote. This electoral system is a tweaked version of the German-style mixed-member proportional (MMP) system and rarely used elsewhere. It will make the Thai party system more fragmented and difficult for any party to win a clear majority. A weak coalition government would thus be a likely outcome. It will also hurt the major and small parties but help the medium-sized parties. Allen Hicken and Bangkok Pundit (pseudonym), who ran a simulation using the 2011 election results to test the effect of the new system, found that Pheu Thai will be the biggest loser in this system as their seats will reduce from 265 (53\%) to only 225 (45\%). Meanwhile, according to the simulation, Democrats will receive roughly the same number of seats under the new system. The biggest winners are the medium-sized parties like Bhum Jai Thai, Chart Pattana Pheu Paendin, and Chart Thai Pattana (Hicken and Bangkok Pundit 2016). This has significant implications as there is widely shared belief that the junta plans to co-opt these medium-sized parties in the new elections. With the medium-sized parties' support and the 250 votes from the junta-appointed senate, they can decide who will be the prime minister (Kom Chad Luek 19 May 2016; Post Today 14 April 2016).

Overall, Meechai's constitution is designed to give more concrete power to an unelected elite minority - the army, the judiciary and independent organisations. Elected government and executive leaders are easily disqualified. The government's use of budget is monitored and constrained by independent organisations. Policy implementation is limited and constrained by various unelected institutions. Moreover, government could not implement any policies that contradict the 20-year national reform strategic plan laid out by the NCPO (Prajak 2016). The voters' electoral mandate will be less meaningful in deciding who should govern. It does not matter much which parties, Democrat or Pheu Thai, win the elections because the elected government will be placed under the control of the unelected minority elites with the military at the top of the power structure.

With the army's institutionalised power embedded in the constitution, military elites have designed new mechanisms to seize power without resorting to a military coup. The institutional design created by the 2017 charter could thus be characterised as military-guided semi-authoritarianism. Through the institutional (mis)design, the military elites 'tame' the majoritarian democracy. Everything considered, the army maintains their position as the dominant power while other institutions and political forces grow weaker and less united. The following sections demonstrate that the military has not only embedded 
themselves within the formal constitutional structure but also in political and civil societal spheres.

\section{The Entrenchment of Military Power: Institution, Nepotism, and Cooptation}

The previous section explained the context of the 2014 coup and the military's institutional design to maintain their power in the future. This section analyses strategies and mechanisms the Prayuth regime utilised to entrench military power at the expense of other political institutions and groups.

Even though the 2014 coup was a continuation of the 2006 coup, the power structure and governing rules of the 2014 coup leaders are significantly different. In the 2014 coup, the army leaders established direct military rule in which power and decision-making processes were centralized in the military institution and junta leaders. The coup regime of General Prayuth is divided into five organs: the NCPO, Cabinet, National Legislative Assembly (NLA), National Reform Council (NRC) and Constitution Drafting Committee (CDC). It is clear from the composition of each organ that the military dominates the power structure.

First and foremost, the NCPO as the most powerful organisation after the coup is completely controlled by the junta. ${ }^{6}$ The coup leader Prayuth made himself Prime Minister instead of giving the position to a non-military leader like in the 2006 coup. All key ministries related to national security, including Defence and the Interior, are likewise controlled by military leaders. Besides, the junta stepped in to control other ministries that went beyond their knowledge and expertise, including the Ministry of Foreign Affairs, Transport, Agriculture and Cooperatives, Natural Resources and Environment, Energy, Commerce, Labour, Justice and Education. ${ }^{7}$ The Prayuth cabinet is predominantly a military cabinet. Compared to the coup-installed government of general Surayud Chulanont (2006-07), one can clearly see the stark difference. Surayud was not among the coup leaders but was appointed because of his position as a privy councillor trusted by the king. Besides Surayud, who was prime minister and minister of the Interior, his whole cabinet had only two military figures in charge of ministries, namely, Defence and Transport. The rest were conservative technocrats, highranking public servants, businessmen, academics, and civil society leaders (Asian Tribune 2006). If the 2006 coup was a coup of royalists carried out by the army, the 2014 coup was a coup of the army by the army. In other words,

\footnotetext{
${ }^{6}$ There is only one civilian appointed to the NCPO: Meechai Ruchuphan, who is the chairman of the constitutional drafting committee.

${ }^{7}$ Later on, due to the apparent incompetency and serious errors that took place within several ministries under the control of these military cabinet members, the NCPO eventually had to replace them with more capable civilians. The ministries that saw reshuffles were those of Foreign Affairs, Transport, and Commerce. At the Ministry of Education and Justice, military generals also stepped down because they were appointed by the new king to the privy councillors (Sasiwan 2016).
} 
in the post-2014 coup politics, the military are not merely instruments of rule but the actual rulers.

In the 2006 coup, the junta leaders (which governed the country for only 15 months) appointed 65 military personnel to serve in the 242-member coupinstalled National Legislative Assembly (NLA). Military therefore accounted for only $26 \%$ of the Assembly. In the 2014 coup, the figure rose to 58\% (145 out of 250 NLA members). The rest of the NLA members are divided between police (5\%), civilian bureaucrats (26\%), businessmen (8\%), and others (3\%). ${ }^{8}$ Among the 145 military men who sit in the Assembly, 90 are active soldiers while the other 55 are retired. The interesting feature is that every chief of the army, navy, and air force since 2007 is appointed by Prayuth as NLA members. This reflects an attempt by the NCPO to base its rule on the army institutional basis. However, it should be noted that nepotism is also present in the Prayuth regime. Prayuth appointed 36 of his former subordinates, seventeen of his classmates, and his own younger brother to positions in the NLA. Prawit Wongsuwan, another key NCPO leader and defence minister, appointed two of his younger brothers to the NLA. Besides Prayuth's and Prawit's families, four other leading military families are strongly represented in the NCPO and NLA: Ruddit, Kerdpol, Sitabutr, and Nakwanich. ${ }^{9}$ This pattern of creating political dynasties within the military regime is not unprecedented in Thailand. It previously occurred in the 1970s under Field Marshal Thanom Kittikachorn's government when Thanom and his assumed successor, Field Marshal Praphat Charusathien, made an attempt to promote Colonel Narong Kittikachorn, Prime Minister Thanom's son and Praphat's son-in-law, as political heir of the Thanom-Praphat clique. This dynastic building effort led to serious internal conflicts within the army and partly contributed to the end of the military regime in 1973 (Prajak 2012: 247-250).

More importantly, members of these powerful military families, Kampanat Ruddit, who had served in several high-ranking positions including assistant Army chief, NLA member, and director of the NCPO's Centre for Reconciliation for Reform, and Teerachai Nakwanich, former Army chief and former member of the NCPO were appointed as new privy councillors by King Maha Vajiralongkorn after he ascended the throne. ${ }^{10}$ This appointment revealed the strong linkages and interdependence between the new monarch and the influential military families in the transitional era. All things considered, the strong institutional support base of power helped explain the longevity of the NCPO's power and its successful control. The mixed elements of institutional and personalised

\footnotetext{
${ }^{8}$ https://ilaw.or.th/node/4407 (accessed 2 June 2017).

${ }^{9}$ https://ilaw.or.th/node/4407 (accessed 2 June 2017).

${ }^{10}$ According to the 2014 interim charter of the NCPO, the King can appoint up to nineteen privy councillors including the president. After ascending the throne, the King appointed thirteen privy councillors, six of which were first time councillors, including Kampanat and Teerachai.
} 
rule of the Prayuth regime, however, could be a potential source of internal conflict within the regime in the future.

The National Reform Council (NRC), comprised of 250 members, is appointed to formulate the 'reform proposal' for the country. Compared to the NLA, the NRC has no actual power but the NCPO clearly uses it as a platform to co-opt and reward the coup coalition - a group of people in civil society and political society who have been involved in the anti-Thaksin movement, which paved the way for the 2014 military coup. The NRC's members include active and retired public servants, prominent academics, wealthy businesspersons, high-profile senators, yellow shirt and People's Democratic Reform Committee (PDRC) leaders, leading NGO activists, famous journalists and politicians from several parties. ${ }^{11}$

Through the NRC and other newly found committees and sub-committees, the junta played the politics of cooptation by providing their coalition and potential opposition forces public positions, financial gains and a formal space to voice their demands. The NCPO has made these crucial actors in political and civil society feel that, at least, they have some access to power and interests under the military-controlled authoritarian regime. As for the technocrats, academics, journalists and NGO activists, even though some of them were sceptical of the NCPO, they were pragmatists and saw this opportunity to push forward their policy agendas and voice their grievances. ${ }^{12}$ The group of unelected professional elites who gained privilege and material benefits from joining the junta's administration and political bodies has become an integral body that helped protect and sustain military rule. By successfully co-opting various groups of people, the NCPO developed a support base in political and civil society.

In the new era of transition after the royal succession in October 2016, the royal-military elite are changing in their power structure and relationships with each other. The long-established political order centred on a charismatic and popular monarch loyally served by the army could no longer properly function without the late King Bhumibol Adulyadej. The new political order in the post-King Bhumibol era has not yet been clearly established. The military does not want a power vacuum to occur in this fragile time. The army strongly believes that its institution alone can ensure an orderly and peaceful transition. Moreover, the army aspires to control the direction that this transition takes. The military, as the old elite in Thailand, stepped in during the fragile time of royal succession to become the new ruler who controls, dictates and decides the distribution of power and interests in the new reign. Consequently, the military is in the process of creating relationships with other social and political forces, namely,

\footnotetext{
${ }^{11}$ For the background and roles played by these professional elites both before and after the 2014 coup, see a comprehensive analysis by Veerayooth (2016).

${ }^{12}$ Interview, a leading technocrat working for the NCPO, Bangkok, 13 December 2016; interview, academic who was connected to the NCPO, Bangkok, 29 May 2017.
} 
influential capitalists, which is similar to the Sarit era, when army leaders and some groups of capitalists formed alliances for mutual benefit.

From what we have seen after the coup, the military seeks to place itself in the position of a hegemonic ruler, dominating power in the long term and not allowing others to gain access to this power or form an alternate elite group. We can clearly see this in the budget: increased privileges, salaries and troops; an expansion of the situations in which military power can be used; the placing of military personnel in charge of state enterprises and state as well as independent organizations and, most importantly, enshrining this power within the constitution. Since the coup, military generals manoeuvred to control the lucrative state-owned enterprises (SOEs). In 2017, 40 SOEs have military personnel as their board members, which is a $100 \%$ increase from the pre-coup era, and sixteen enterprises have military generals as their board presidents, a five-fold increase from the civilian administration before the coup (BBC Thai 2017). Most importantly, by having the 250 senators (half of the Lower House) directly appointed by the NCPO, the military practically becomes the largest political party in the new political system that can nominate and select its own prime minister (Prajak 2016).

\section{Depoliticising Society: Suppression and Demobilisation}

Another key characteristic of the Prayuth regime is its attempt to manage dissidents and depoliticise society. In the foregoing section, we discussed the regime's successful co-optation of civil society groups into the coup coalition led by the junta. Nonetheless, not every civil society group has been co-opted into the coup coalitions.

After the coup, a group of progressive red-shirt activists, academics and student leaders have remained critical of military rule and made efforts to protest against the regime. These anti-coup dissidents were perceived by the Prayuth administration as a potential force for destabilising the regime and thus needed to be marginalised and silenced through intimidation and repression. Given the small number of anti-coup activists, the NCPO has pursued a strategy of specifically targeted repression instead of random and widespread coercion. The NCPO has detained a large number of dissidents in military camps, forced them to go through 'attitude adjustment programs' (i.e. intimidation and psychological torture), arbitrarily visited their houses and workplaces and taken them for interrogation and charged them with various kinds of draconian laws entailing severe punishment (Haberkorn 2014; Nanchanok 2015). ${ }^{13}$

The ultimate aim of these repressive measures is not taking lives but creating fear and silence, making targeted dissidents fearful of making public comments

\footnotetext{
${ }^{13}$ Also see an excellent study by Paungthong (2017), showing the increasing role of Internal Security Operations Command (ISOC), the state security organisation in charge of a wide range of civil affairs, in conducting psychological operations and penetrating the socio-political sphere in various parts of the country.
} 
or mobilizing mass protests against the junta. Given the divided and weakened bureaucratic machine (see next section), the Prayuth regime has not aimed for absolute thought control operated by a totalitarian state but has sought an actual depoliticisation of society. It tries to carry out a process called 'privatisation', which aims to shift citizens' attention from public affairs to private matters (Linz 1970: 261-264). In this regard, the post-2014 military regime can thus be characterised as a 'depoliticising, low-mobilisation regime' - a regime that attempts to deactivate and exclude the popular sector similar to what we observed in Argentina and Brazil in the 1960s (O'Donnell 1979: 90, 108) and Thailand in the 1960 s under Field Marshall Sarit. ${ }^{14}$

In sum, by combining co-optation with a depoliticising strategy, the Prayuth administration had hitherto successfully controlled civil society, suppressed street politics, and thereby avoided confrontation with the masses that could potentially lead to a popular uprising. As the literature on the post-Cold War military politics points out, a military regime that bases its power upon co-optation and institutional mechanisms, not merely violent suppression, tends to last significantly longer than those using personalised rule and intensive coercive tactics (see Kendall-Taylor and Frantz 2015; Gandhi and Przeworski 2006: 1-26; Boix and Svolik 2013: 300-316). The Prayuth regime seems to follow this authoritarian trail.

\section{The Resurgence of Bureaucratic Polity?}

The military's increasing dominance raises an important question of whether Thailand has returned to the so-called 'bureaucratic polity' (e.g. Puangthong 2015). ${ }^{15}$ This is a term originally coined by Riggs (1966) to characterise Thailand as a country in which power is centralised within the bureaucracy and all decision-making processes and policy implementation are carried out by the bureaucratic apparatus. This section aims to illustrate the more complicated picture of Thai politics after the 2014 coup and argues that the Prayuth regime has, in fact, weakened the bureaucracy rather than strengthened it. The Thai bureaucracy has been politicized and demoralized by the uncertainty and unpredictability created by the arbitrary and absolute power of the Prayuth administration. Civilians increasingly lack morale and drag their feet when faced with the arbitrary use of military power and decree. This situation has led to increasing levels of inefficiency and disunity within the bureaucracy and the resulting delay and failure of the junta's reform efforts.

\footnotetext{
${ }^{14}$ The 'mysterious incident' of the disappearance of Yinckluck Shinawatra could also be understood through this depoliticising framework. On 25 August 2017, the former prime minister vanished from Thailand before a Supreme Court verdict in a negligence case against her. Most analysts believed that the NCPO preferred to see her flee, rather than putting her in jail and arousing the mass mobilisation of angry 'red shirts' (see Marwaan 2017).

${ }^{15}$ Supalak Ganjanakhundee also follows this argument. Available at www.nationmultimedia.com/ news/national/aec/30240338 (accessed 1 June 2017).
} 
Since the beginning, the coup leaders were faced with the problem of bureaucracy not carrying out policies formulated by the coup government. Prayuth showed his severe frustration in public many time over this problem, lamenting that “...several civil servants are saying to their colleagues, just be patient the junta will be gone within a year. Watch out, I will remove these people immediately, I already have a list [of these people]. Do not dare to bad-mouth like this again. I am angry. You cannot say something like this. These people do not love their country. They do not deserve to be civil servants". ${ }^{16}$ Despite his strong words, the situation was apparently unchanged as he had to return to this issue over again with more frustration. Other cabinet members also complained about this problem. For example, the Minister of Agriculture complained that he had to write plan and project details by himself because his subordinates were doing nothing and not obeying orders. He threatened to demote every head of department if the situation did not improve (Manager Online 2014). Not only the coup leaders, but also the public seems to be informed and well aware about the bureaucrats' inefficiency and failure to take required action. In public opinion surveys regarding the administration of the government and people's concern after the 2014 coup, 79.4\% of respondents identified the foot-dragging behaviour of the civil servants as their topmost concern. The respondents pointed out that this problem would prevent the military government from achieving its goals to reform the country (Post Today 24 December 2016).

There are two main reasons for the inaction of civil servants under the coup regime. The first crucial factor is the disunity within the bureaucracy. The 2014 coup occurred when Thailand was undergoing its deepest polarisation in modern history between the anti- and pro-Thaksin movements. This polarised conflict extended to every section in society, including the bureaucracy. After the 2006 coup, Thai bureaucracy was extensively politicised and divided by the interference of elites from both sides of the conflict as they sought to use the bureaucracy as political tools to weaken their opponents. Consequently, the bureaucracy's lack of unity might have helped weaken the elected government before the coup, but it likewise debilitates the military government. Prayuth has ruled the country with absolute military control, but his administration operated under a divisive and weak bureaucracy unlike his predecessor field marshal Sarit Thanarat who governed the country during the 1950s with despotic paternalism supported by a strong bureaucratic polity (see Thak 1979).

Second, from a long-term perspective, the frequent change of governments and regimes since the 2006 coup has demoralised bureaucracy along the way. Back to 2006, the military-installed government lasted for only fifteen months. Both high-ranking and low-ranking bureaucrats thus adapted their behaviour

\footnotetext{
${ }^{16}$ Prayuth Chan-ocha gave this interview to the media on 21 November 2014 (Kom Chad Luek 2015).
} 
to the unpredictable and fast-changing political environment. Under the coupinstalled government, regime longevity is not certain and thereby the rational public officers would prefer to be foot-dragging or inactive because they know that if they actively follow orders of the junta during the coup regime, they could be demoted when an elected government comes back to office. More importantly, given that the NCPO regime tends to ask civil servants to carry out tasks by bypassing the normal procedure or bureaucratic rules, bureaucrats feel uncomfortable and unsafe pursuing those tasks as they would be the ones held responsible for any wrongdoing (Thai PBS News 2016). A good example is the controversy concerning the Yingluck Shinawatra government's rice-pledging scheme. The junta demanded that Yingluck and her former ministry officials involved in the government-to-government $(\mathrm{G} 2 \mathrm{G})$ sale of 6.2 million tons of rice to China pay 20,000 million baht in compensation for damages caused to the state. However, the civilian commerce minister appointed by the junta hesitated to sign the administrative order to demand compensation as there is no law allowing the ministry to seize assets. The minister then asked the permanent secretary of commerce to sign the order on behalf of the ministry. The permanent secretary refused to sign and told the media that she would quit if she was forced to do this. Foot-dragging and inaction witnessed in the bureaucratic system are thus the discernible outcome.

The NCPO and Prayuth tried to solve the problem of government officials' inaction by using section 44 of the interim constitution, which was promulgated by the NCPO on 22 July 2014. Section 44 granted absolute and unchallengeable power to Prayuth as head of the NCPO. The main purpose of Section 44 is that, in any case deemed necessary, the head of the NCPO could issue any order to solve urgent problems and to strengthen public unity and harmony, regardless of whether such act enters into legislative, executive, or judicial prerogative. In this regard, all orders, acts as well as performance in compliance with such orders shall be deemed lawful and constitutional. With its arbitrary nature and wide scope of power, section 44 has become a beneficial tool utilised by Prayuth to tackle numerous difficult tasks. Within three years of the coup administration, Prayuth has issued 152 orders in total through section 44. These orders were used to solve a wide range of issues, from suppressing the freedom of assembly and association, solving the problem of migrant workers, enacting measures and policies on the utilisation of public land, creating the special economic zones, solving the problem of illegal, unreported and unregulated fishing, solving the problem of overpriced lottery tickets, appointing the selection committee of the National Anti-Corruption Commission (NACC), eliminating the local mafia, arresting the allegedly corrupt head monk of a controversial Buddhist sect, to solving the problem of delinquent youth and prohibiting local people in the northeast from performing their traditional rituals (iLaw 2015; Workpoint News 2017). 
Investigating closer, however, one finds that section 44 has been used mostly to tackle the bureaucratic predicament. Government officials' inaction and disunity have clearly become a critical impediment to the governing of the junta administration. Among 152 orders, almost half (70) of them were issued to remove, transfer and demote government officials and dissolve dysfunctional public organisations. By May 2017, a total of 331 government officials were removed and transferred as they were accused of involvement in corruption or failing to do their jobs (Workpoint News 2017). The main targets were government officials perceived by the NCPO as having close relationships with or remaining loyal to Thaksin and Yingluck's administration. These officials, including those who worked in the parliament secretariat, prime minister's office, intelligence community and national security, were discharged or demoted since the early phase of the regime, and some of them were investigated and legally charged with corruption and misconduct (Prachachat Thurakij 27 March 2017). ${ }^{17}$ Besides, the junta removed 69 highest-ranking civil servants, many of whom were permanent secretaries or heads of department in several ministries, from their positions, a practice that has never been witnessed before in previous coups or under civilian governments (Thai Rath 27 June 2014; Prachachat Thurakij 27 March 2017). Two hundred fifty-eight middle-ranking and low-ranking government officials at both national and local level were suspended for alleged corruption. These cases drew criticism from the officials involved and public because the allegations were unclear or unsupported by concrete evidence. Furthermore, there was no ensuing investigation and/or public announcement regarding whether these public officials were eventually convicted or acquitted (Isara News 2016).

Besides section 44, in some cases the coup government removed senior officials through cabinet decisions. These top bureaucrats were not accused of corruption but were removed because of their insubordinate behaviour. Two highprofile cases were the removal of the permanent secretary of the Natural Resource and Environment Ministry, Mingkwan Witchayarangsarit, and the permanent secretary of the Tourism and Sports Ministry, Areepong Bhoocha-oom. These two senior officials were reportedly in conflict with the junta as they refused to implement policies and/or take action damaging public interests (ASTV Manager Online 19 May 2015). Areepong was an exemplar case reflecting the dysfunctionality of the bureaucratic system under NCPO control; he was removed from his position at the Ministry of Tourism and Sports after being appointed by the junta only two months earlier. After being removed, he told the media, "I think I am doing the right thing, but the result is being removed. It is not fair. I was sad" (Post Today 10 September 2015). ${ }^{18}$

\footnotetext{
${ }^{17}$ Available at http://www.prachachat.net/news_detail.php?newsid=1490505671 (accessed 30 May 2017).

${ }^{18}$ Available at http://www.posttoday.com/analysis/interview/387195 (accessed 28 May 2017).
} 
After all, the harsh measures taken by the NCPO in 'ordering' the bureaucracy and to 'make bureaucracy work' seemed to create negative outcomes and backlash as it further demoralised the officials and ironically weakened the bureaucracy as an institution. Accordingly, we argue that the Prayuth regime is not a return to the bureaucratic polity with a strong, effective, and united state apparatus witnessed in the 1960-1970s. Instead, the 2014 coup has been a move towards military rule based on a dysfunctional and divided bureaucracy.

\section{On the Verges of Electoral Politics}

On 10 October 2017, Prime Minister Prayuth Chan-ocha announced that Thailand would hold a general election in November 2018. At Government House, the junta chief told a group of reporters that "around June we will announce the date for the next election. Then in November we will have an election" (The Nation 10 October 2017). Soon after, this schedule of general elections was pushed back to February 2019 (The Nation 27 February 2018). It is important to note that the junta has announced election dates several times since the coup, all of which were later postponed by citing security concerns and claiming that a return to democracy would stir up polarised conflicts and street violence.

Another interesting political move by the Prayuth government occurred in early November 2017, when Prayuth posed a set of six political questions to the public. The first two questions were the most telling and important ones; they asked Thai people "Do we need new political parties or new politicians for the people to consider in the next general election?" and, "Does the NCPO have the right to support a political party?" (Bangkok Post 10 November 2017). This set of questions clearly revealed the political intentions of the junta and unequivocally signalled that the junta aspires to retain its power after the next election. Thus, there is a strong possibility that the NCPO will set up or tacitly support political parties to contest in the coming poll to ensure that Prayuth and his colleagues return to control the country after the election. ${ }^{19}$

\section{State-Business Relations: Pracharath and Hierarchical Capitalism}

This section explores the state-business relations under the Prayuth regime. It first elaborates on the origins, coalitions and policy schemes pursued under the so-called Pracharath model, an overarching economic theme of his government.

\footnotetext{
${ }^{19}$ As of March 2018, there are moves from military officers and politicians to establish parties supporting Prayuth's return to power in the next elections. These pro-military parties include, for example, the Reform People Party initiated by former senator Paiboon Nititawan, the Great Mass of People Party initiated by PDRC leader Suthep Thaugsuban, and the 'Palang Pracharath' party led by a group of retired military officers, whose party name makes a reference to the Pracharath scheme of NCPO government (Khaosod English 12 March 2018).
} 
Then it discusses whether, and in which ways, this supposedly new model has altered relations between the state and business sectors. It argues that Pracharath reflects the collective endeavours of Sino-Thai business tycoons to constitute 'hierarchical capitalism', characterised by their crafting of a hierarchical mode of economic participation and reinforcement of power asymmetries in the economy, in the circumvention of a 'level playing field' competition.

\section{Origin and Partners}

"We make a pact together to solve problems and fix past mistakes. This is not populism. It is cooperation between the government and the people". Prayuth Chan-ocha (Bangkok Post 21 September 2015)

The Pracharath initiative was launched in September 2015. The term is part of the lyrics of the Thai national anthem and was used before in the Eighth National Social and Economic Development Plan (1997-2001). It entails a partnership between the government and the people, with pracha literally meaning people and rath meaning the state. There is no precise English translation for the term. Many have suggested "civil state" but the government spokesman's office prefers "a state of the people" (The Nation 19 October 2015). Prayuth offered his own explanation: "In a sense, Pracharath means the prime minister is the 'rath' [state] who reaches out to the people for a common agreement to create stability from the foundation up" (The Nation 1 October 2015). In general, the government uses Pracharath to mean a partnership formed between the state, the private sector, and the public, with the aim of strengthening the country's economy at the local level. The political drive is clear: to create a catchy new characterisation that distances the regime's grass-roots development policy from that of Thaksin's populism (Prachaniyom), as well as co-opting the voting base of Thaksin in the provinces.

The two masterminds behind the model are Somkid Jatusripitak and Prawase Wasi. Somkid, Deputy Prime Minister, has a strong connection with the communities of Sino-Thai tycoons. He was one of the founding members of Thaksin's Thai Rak Thai Party and held key economic posts in the Thaksin governments from 2001 to 2006. However, since the military coup in 2006, he has defected from Thaksin and in 2009 joined Prawase in the establishment of the Right Livelihood Foundation, which appears to provide a platform for amalgamating business magnates with civil society protagonists. Prawase is a leading royalist intellectual and the most prominent figure of Thailand's nongovernmental organisations (NGOs). He is a key architect of powerful 'autonomous government agencies', especially the Thai Health Promotion Foundation and the Community Organisation Development Institution (CODI), which has 
flourished since the promulgation of the 1997 Constitution (see Harris 2015; Thorn 2016). ${ }^{20}$

On the business side, a total of 24 major conglomerates signed a partnership deal to support the Pracharath initiative in December 2015. These included the Thai Beverage Group, Charoen Pokphand Foods/True Corporation, Mitr Phol Sugar, Central Group, The Mall Group, Thai Union Group, Bangkok Bank, SCG Group, Thai President Foods, Saha Group, Samart Group, Thai Vegetable Oil, WHA Corporation, Ch Karnchang, Advanced Info Service, Pruksa Real Estate, MK Restaurant, Se-Ed Education, Muang Thai Insurance, BTS Group Holdings, Bangkok Airways and PTT Group (The Nation 2015). Isara Vongkusolkit, Chairman of the Thai Chamber of Commerce and the Board of Trade, as well as owner of Mitr Phol Sugar, was appointed Chair of the Pracharath's privatesector committee and deputy chairman of the Pracharath's executive committee. The junta claimed that the business sector has been brought in to play a role in assisting lower-income earners by providing knowledge and market access, as well as improving the education system (The Nation 4 December 2015). Yet, there is a quid pro quo in the deal, as Somkid announced that the Board of Investment and the Ministry of Finance would offer certain privileges to private companies joining the initiative (Bangkok Post 14 January 2016).

While the business partners are supposed to offer know-how and market access, Prawase-led NGOs will provide the bright ideas and the links to grass roots communities. Upon the launch of the Pracharath, Prawase gave a lecture on the solution to rescuing Thailand from the 'black hole' by replacing a massive one-time financial injection with holistic development, emphasising concepts such as livelihood rights, people's participation, bottom-up planning, environmental conservation, green farming, and community banks (Bangkok Post 23 September 2015). The partnership from the civil society side would be run by Poldej Pinprateep, a close ally of Prawase, and his network around the CODI, which has strong connections with other NGOs, community-based organisations and several people's movements. When questioned about this 'strange bedfellows', namely, civil society and big business, Poldej replied, "We have good communication, and hold regular updating and brainstorming sessions. We also hold public forums to educate people nationwide" (The Nation 20 June 2016).

\section{The Outreach Programs}

Despite a promising start, from its launch in September 2015 until the end of 2017, most of the projects implemented under the Pracharath umbrella have

\footnotetext{
${ }^{20}$ Politically, Prawase Wasi is "a rare syncretistic figure who commanded considerable respect both within the bureaucracy and among NGO leaders and social activists" (McCargo 2005: 511). Ideologically, he usually speaks "both the language of national ideology (nation, religion, king), and the language of empowerment (community and rights)... [reflecting] the continuing effort by the aristocratic establishment...to place itself at the moral centre of national development problems" (Connors 2003: 159).
} 
been haphazard and ad hoc. At the outset, the Pracharath was announced as part of the government's 136-billion-baht stimulus package approved by the cabinet in late 2015. Specifically, it was composed of three main measures aimed at supporting small- and medium-sized enterprises (SMEs), as well as farmers and lowincome earners. First, the state-owned Bank for Agriculture and Agricultural Cooperatives (BAAC) and the Government Savings Bank (GSB) would be the lenders of a seven-year-term loan to 59,000 village funds at one million baht each. They would offer interest-free loans for the first two years, with the government subsidizing the interest. Second, the Interior Ministry would allocate 36.275 billion baht to 7255 tambons. Each tambon would receive five million baht to implement any project related to building or repairs in the area and development projects in line with King Bhumibol's philosophy of sufficiency economy. Finally, the government would call for state agencies and SOEs to accelerate budget disbursement for small projects worth less than one million baht nationwide (Bangkok Post 21 September 2015).

Later, in early 2016, the government set up twelve steering committees, ranging from Innovation and Digitalisation to Modern Farming, each of which is led in pairs by one minister and one executive from either a private firm or industry association (see Table 1). It was reported that the government allocated 250,000 million baht in this fiscal year budget for all the Pracharath projects (MGR Online 10 February 2017).

\section{Pracharath Rak Samakkee}

Among the most concrete projects under the Pracharath umbrella appears to be the Pracharath Rak Samakkee, a scheme aimed at establishing local enterprises in every single province. According to Poldej, this newly set-up enterprise will be collectively formed by the state bureaucracy, business, and local people, with flexible ownership proportional among the tripartite forms of operation. The pilot enterprise began in Phuket. It was set in motion by Thai Beverage and eventually, this private entity is expected to withdraw and allow local communities to run the business themselves. However, dividends will not be paid to shareholders rather, they will be reinvested in the venture. Phuket's Pracharath Rak Samakkee has been overseen by the state-business pairing of General Anupong Paochinda, Interior Minister, and Thapana Sirivadhanabhakdi, CEO of Thai Beverage. Local representatives will also participate in the management to ensure that local residents benefit from the enterprise (The Nation 20 June 2016). This social enterprise in Phuket has been endowed with an initial capital of five million baht, with Thai Beverage putting in one million baht, and with another one million baht being raised from the local business community. It will work on adding value and the branding of key products, including pineapple, lobster, goats' milk, batik, and organic vegetables (Thitinan 2016). After Phuket, four other provinces (Phetchaburi, Udon Thani, Chiang Mai and Buri Ram) will follow suit in the first 
Table 1. Twelve sets of public-private steering committees

\begin{tabular}{|c|c|}
\hline Steering committee & Joint leaders (government-business) \\
\hline 1. Innovation and digitalisation & $\begin{array}{l}\text { Ministers of Digital Economy and Society and } \\
\text { Ministry of Science and Technology - Kan Tra- } \\
\text { kulhoon (SCG) }\end{array}$ \\
\hline 2. SMEs and start-ups & $\begin{array}{l}\text { Ministry of Industry - Kalin Sarasin (Chairman of } \\
\text { the Thai Chamber of Commerce and former } \\
\text { CEO of Siam Cement Trading) }\end{array}$ \\
\hline 3. Tourism and $\mathrm{MICE}^{21}$ & $\begin{array}{l}\text { Ministry of Tourism and Sports - Chanin Donavanik } \\
\text { (Dusit Thani Hotel) }\end{array}$ \\
\hline $\begin{array}{l}\text { 4. Export promotion and outward } \\
\text { investment }\end{array}$ & $\begin{array}{l}\text { Ministry of Commerce - Sanan Angubolkul (Srithai } \\
\text { Superware) }\end{array}$ \\
\hline 5. New S-Curve & $\begin{array}{l}\text { Ministry of Industry - Prasert Bunsumpun (PTT } \\
\text { Global Chemicals) }\end{array}$ \\
\hline 6. Modern farming & $\begin{array}{l}\text { Ministry of Social Development and Human } \\
\text { Security - Isara Vongkusolkit (Mitr Phol Group) }\end{array}$ \\
\hline $\begin{array}{l}\text { 7. Investment attraction and } \\
\text { infrastructure development }\end{array}$ & $\begin{array}{l}\text { Ministry of Finance - Chartsiri Sophonphanit } \\
\text { (Bangkok Bank) }\end{array}$ \\
\hline 8. Competitive workforce & $\begin{array}{l}\text { Ministry of Education - Roongrote Rangsiyopash } \\
\text { (SCG) }\end{array}$ \\
\hline $\begin{array}{l}\text { 9. Grass-roots economic } \\
\text { development }\end{array}$ & $\begin{array}{l}\text { Minister of Interior - Thapana Sirivadhanabhakdi } \\
\text { (Thai Beverage) }\end{array}$ \\
\hline 10. Regulatory reform & Deputy Prime Minister - Kan Trakoonhun (SCG) \\
\hline 11. Human capital development & $\begin{array}{l}\text { Ministry of Education - Suphachai Chearavanont } \\
\text { (True Corporation) }\end{array}$ \\
\hline 12. Social & $\begin{array}{l}\text { Ministry of Social Development and Human } \\
\text { Security - Isara Vongkusolkit (Mitr Phol Group) }\end{array}$ \\
\hline
\end{tabular}

Source: Authors' compilation.

phase. The committee plans to set up this type of local social enterprise in all 76 provinces.

In 2017, products from some provinces under the brand Pracharath Rak Samakkee were brought, together with existing goods from the Thaksin-initiated the One Tambon One Product (OTOP) project, to display and sell at the Thailand Best Local Product exhibition near Government House. In May 2017, Poldej claimed that the scheme has now involved 13,000 households and increased their income by approximately 358 million baht per month (Post Today 21 May 2017).

\section{Tourism and hospitality}

The Pracharath has also been involved in several projects and schemes with a less clear result and progress than the Pracharath Rak Samakkee. One of the highprofile campaigns is found in tourism, led by the pairing of the Minister of

${ }^{21}$ Meetings, incentives, conferences and exhibitions (MICE) are currently regarded as high-yield sectors in tourism. 
Tourism and Sports, Kobkarn Wattanavrangkul, and Chanin Donavanik, an executive from the Dusit Hotel Group. The project's main objectives are threefold: paving the way for sustainable development; increasing tourism revenue; and spreading income to rural communities nationwide (The Nation 2016). In doing so, the Association of Thai Travel Agents would create a package for Thai food and farm visits targeting the six million customers who travel with its members annually, with twelve of the country's best rice farms being the hosts. Chanin himself came up with the idea of Quick Win tourism, which includes promoting the meetings, incentives, conferences, and exhibitions (MICE) industry, upgrading Thailand as a shopping paradise, extending the length of visas for retirees from Japan and some European countries, and launching a one-stop website for tourism information (Bangkok Post 15 February 2016). Yet, thus far there has been no clear evaluation of the project's impact.

Another project is the Pracharath Hospital Scheme, which plans to encourage local people to "assume a sense of ownership" of their local hospitals and to participate in various kinds of development activities. Public Health Minister Piyasakol Sakolsatayadorn also noted that "People have more say in hospital affairs as they are asked to donate 3 baht a day or 1,000 baht a year to the hospital" (Bangkok Post 7 June 2017). According to Piyasakol, this policy will be implemented in 38 community hospitals in its first phase between July and September 2017. By September 2019, all community hospitals will be brought under the scheme (Bangkok Post 7 June 2017).

\section{Donations and royal pardons}

In addition to the projects undertaken by ministers and the twelve steering committees, Prime Minister Prayuth himself has moved to establish several ad hoc schemes under the name of Pracharath, ranging from fundraising to royal pardons. During the severe floods in the southern provinces in January 2017, the government held a special TV pool programme entitled 'Pracharath Ruamjai Chuay Utokkapai Paktai' (Pracharath joining together to help Southern flood victims). This fundraising campaign, led by Prayuth, provided a platform to donate to those affected by the storms. For example, PTT donated 20 million baht, while Thai Beverage and CP gave ten million baht each. Prime Minister Prayuth also spared savings of 100,000 baht for the charity. Within two hours, the government had successfully raised 329 million baht (Bangkok Post 18 January 2017).

On another occasion, Prayuth launched the 'Pracharath Huangyai Mai Thodthingkan' (Pracharath cares and will not leave anyone behind) to support convicts released under the royal pardon. The first batch considered approximately 200,000 inmates to be eligible for a reduction in their jail sentences to various degrees or even suspended jail terms. Around 3,000 of them, including youths, disabled, sick or elderly inmates, have been released under this scheme (The 
Nation 20 August 2016). Apparently, almost everything could be considered part of the Pracharath.

It is worth noting that most of the key business partners who formed the Pracharath projects have later been appointed as part of the National Strategy Committee authorised to draft the plans for a 20-year national strategy that critics say will allow the military to control future elected governments.

\section{Beyond Pracharath}

Alongside the Pracharath, there have been several policies and decisions made by the Prayuth government that reflect its close relationship with big business and raise questions about conflicts of interest. For example, Isara Vongkusolkit, deputy chairman of the Pracharath's executive committee, is the owner of Mitr Phol Group, Thailand's top sugar producer. When Isara talks about agricultural upgrading in his former role, he also pushes forward the agenda of land zoning, which may favour plantation interests, including sugar: "Zoning will be clearly divided in two: one zone for major crops such as rice, rubber, tapioca and sugar, and the other vegetables and fruits. Farmland consolidation will be required, while new technology and machinery will be used to cut production costs and raise productivity" (Bangkok Post 20 January 2016). The government agreed and imposed zoning regulations on cash crops based on his suggestion to govern local farmers' activities (Bangkok Post 29 January 2016).

Another case in point is the lucrative observatory tower project expected to be Bangkok's new landmark - the Unity Tower. In July 2017, the cabinet had exempted the project from open bidding and directly granted approval to the Bangkok Observation Tower Foundation. The tower, located next to the Chao Phraya River on land owned by the Treasury Department, is expected to be 459 meters in height and cost 4.6 billion baht. Despite this land being very expensive, the Foundation is obliged to pay the Treasury Department only around six million baht per year for a 30-year land lease. The Foundation was originally chaired by Visit Malaisirirat, executive of the property development arm of Charoen Pokphand (CP) Group. The Foundation's directors include representatives from Siam Piwat, the operator of Siam Center and Siam Discovery department stores. Meanwhile, Siam Piwat and CP are working as joint developers of Iconsiam, a high-end, mixed-use project located next to the observatory tower itself. Prayuth responded to public criticisms by insisting that no government budget is required for the project: "This is not a matter of business. The government considered that we should work with them [the private sector] without having to pay any money" (Bangkok Post 29 June 2017).

\section{Towards Hierarchical Capitalism}

As the Pracharath model only came into operation in September 2015, it would be premature to characterise the state-business relationship under the Prayuth regime. However, what we may interpret from all these moves are the aspirations 
of the business leaders in allying with the junta and civil society. The design, rhetoric and platform of the existing outreach programmes reflect the endeavours of Thai business tycoons to constitute what may be called hierarchical capitalism.

The term is used by Schneider (2013) to conceptualise the contemporary capitalist system of Latin America, following the Varieties of Capitalism approach. Unlike both liberal and coordinated varieties found in Western economies (Hall and Soskice 2001), ${ }^{22}$ Latin America has a distinctive, enduring form of hierarchical capitalism characterised by the dominance of familybased conglomerates and multinational corporations alongside low-skill and segmented labour markets. In this system, "hierarchy often replaces or attenuates the coordinated or market relations" (Schneider 2013: 8). Hierarchy is an indictment of power asymmetries prevalent across institutional configurations. Industrial relations are structured by top-down regulations, endorsed by national governments and labour courts. Labour unions have little negotiation power vis-à-vis management within the firm. Direct vertical integration or heavy dependence of small suppliers on large or monopsonist buyers is common. This hierarchical capitalism was consolidated in Latin America by the last quarter of the twentieth century.

Based on the series of projects elaborated above, we argue that the Pracharath model reflects the collective endeavours of Sino-Thai business tycoons to buttress hierarchical capitalism. This argument is made in comparison with, first, the history of Thailand itself and, second, contemporary development in Singapore and Vietnam.

\section{From monopolistic clientelism to the Big Brother Project}

Under Thaksin administrations, the relationship between the state and business in Thailand evolved from competitive clientelism to monopolistic clientelism. In modern Thai history, state-business relations took the form of particularistic links between Sino-Thai entrepreneurs and state officials. From the 1970s until the 1997 Asian financial crisis, the pattern was conceptualised, by Doner and Ramsay (1997), as competitive clientelism, in which the ruling coalitions, either military or civilian, were highly factionalised. Thai firms earned economic rents by gaining privileged positions in the market through their clientelistic connections, but the level of those rents was limited by a degree of competition and fragmentation within the political system. The 1997 financial crisis, along with the new electoral game of the 1997 Constitution, saw the decline of this old pattern and a shift towards a new monopolistic politics under Thaksin, who allied with major family corporations that had survived the crisis to establish the Thai Rak Thai Party (see Thanee and Pasuk 2008).

\footnotetext{
${ }^{22}$ According to Hall and Soskice (2001), the 'liberal market economy' is characterised by arm's length, competitive relations and price signalling, while the 'coordinated market economy' is characterised by within-sector collaboration and long-term labour contracts.
} 
Thaksin's monopolistic control (2001-6) was one of the impetuses that drove the opposing forces to form a coalition to topple his regimes through the two coups d'état (see Veerayooth and Hewison 2017). In the recent anti-Thaksin protests in early 2014, it was reported that the PDRC was supported financially by the leaders of big business groups, whose influence was diminished under Thaksin governments. The list included: Thai Beverage, Mitr Phol Sugar, Saha Pathanapibul, Gaysorn Plaza, Siam Paragon Department Store, King Power Group, Dusit Thani Hotel, Siam Intercontinental Hotel, Riverside Hotel, Wangkanai Sugar, Boon Rawd Brewery, Yakult, Neptune, Thai Namthip, and Muang Thai Life Assurance (Bangkok Post 12 February 2014).

A host of executives of the above conglomerates turned up again as supporters of the Pracharath. When the steering committees were set up, all of them were dominated by military top brass, high-ranking bureaucrats, and these corporate leaders. In joining it, the tycoons justified their collaboration with the government as a collaborative effort to nurture small firms, as well as rural entrepreneurs, by being a 'big brother'. Indeed, and as out of ignorance, one of the new schemes under the Pracharath model has been entitled a Big Brother Project - in which the Finance Minister asked large corporates to support SMEs by assisting the latter with marketing, technology, and financial guarantees in exchange for a tax deduction of 200 per cent of their expenditure (The Nation 2 April 2016). Sontirat Sontijirawong, Deputy Minister of Commerce, explains clearly the incentive for big business: "Companies could save millions and also build their names by participating in the Pracharath Rak Samakee project, as they would not have to invest in separate corporate social responsibility (CSR) endeavors" (The Nation 20 June 2016).

Accordingly, the economic orientation driven by the Prayuth government, especially the Pracharath initiative, well reflects its attempt at crafting a hierarchical mode of economic participation and reinforcing power asymmetries in the Thai economy, in the circumvention of a 'level playing field' competition. Instead of state guidance or a free market, what is happening in Thailand now is the collective pursuit of business tycoons stepping into the countryside to 'nurture' and 'supervise' local enterprises in their respective sectors. Giant agricultural conglomerates nurture provincial farmers, giant hotels nurture local lodgings, and so on. Level playing field competition, considered by many as the best way to promote small business and the country's competitiveness (e.g. Acemoglu and Robinson 2012), has somewhat disappeared and paved the way for a hierarchical mode of economic interaction.

\section{Technocratic governance in Southeast Asia}

The current aspirations of Thai tycoons are comparable to the politics of participation found in the cases of Singapore and Vietnam. As elaborated in Rodan and Jayasuriya (2007), with a long-lasting dominant party in each country, access to public administrative institutions and policy processes are promoted as avenues 
for the technocratic management and resolution of political conflict. The ultimate goal of the People's Action Party in Singapore, as well as the Vietnamese Communist Party, is to "foster a consensual rather than competitive conception of, and framework for, politics" (Rodan and Jayasuriya 2007: 799).

In essence, the Prayuth regime sets out the Pracharath to develop the rural economy. As stated by Apichart Todilokwet, Director-General of the Community Development Department (CDD) and Pracharath's key figure, "The aim is to increase the incomes of rural people and help rural communities raise their standard of living, so we will use financial KPIs to measure the executives' performance" (Bangkok Post 18 April 2016). Nonetheless, as exemplified in the Pracharath Rak Samakkee, the project has been designed without any discussion about transformative issues such as granting local communities the right to manage their resources, be they lands, forest or river basins - as if there were no conflict over resource allocation and public goods in rural areas. What has been pushed forward is a consensual mode of participation. Large conglomerates have been assigned the leading role of Big Brothers vis-à-vis their local counterparts. This mode of interaction, if it persists, can lead to an implication similar to that observed by Rodan and Jayasuriya (2007: 796) in Singapore and Vietnam:

Such administrative modes of participation militate against the mobilisation of independent collective action, notably that entailing class-based collective movements through: the state defining what issues participation can be conducted over; the state controlling who gets access to administrative institutions involving political participation; and the state shaping the form that this access takes. The end result is political rule by administrative means.

What fundamentally separates Thailand from Singapore and Vietnam is that the Thai-style consensual mode of participation is driven by large conglomerates, with the endorsement of the military government, raising the question of direct conflicts of interest. In the East Asian developmental model, the state stepped in to allow resource misallocation in the short term in expectation of long-term efficiency and technological development. By contrast, in Prayuth's Thailand, the state has publicly enabled the tycoons, many of them from oligopolistic and monopolistic markets, to take part in resource allocation at the local level without a tangible long-term objective, needless to say a transparent monitoring system. Whether successful or not, this indicates a concerted attempt to replace competitive markets with hierarchical capitalism - overseen by a small circle of Sino-Thai tycoons.

\section{SUMMARY}

This paper sought to explore the Prayuth regime that began with a military coup in May 2014. Most existing analyses consider the regime to be either the return of 
'Premocracy' or bureaucratic polity. We have disagreed with these statements and indicated how the junta has planned to embed its power in ways different from the past. On the surface, the key characteristics of the Prayuth regime may be in accordance with the definition of authoritarian regimes with four distinctive characteristics: (a) presence of limited political pluralism; (b) absence of elaborate or guiding ideology; (c) absence of intensive political mobilisation; and (d) a leader exercising power within formally ill-defined but quite predictable limits (Linz 1970: 255-259). Nonetheless, the current military regime in Thailand has its own distinctive features. In this paper, we analysed the newly created political structure and political strategies, as well as the newly established relationship among the military, monarchy, bureaucracy, civil society, and business sectors in the post-coup era.

In contrast to Thai politics under the Prem premiership, the Prayuth regime has not pursued a power-sharing governance. It has rather tried to militarise the cabinet, parliament and even state-owned enterprises. Even though elections and party politics would be allowed to operate in the future, the new constitution has already been designed to institutionalise the power of the military as well as the traditional elite vis-à-vis the electoral forces. Meanwhile, this is not simply a return of the bureaucratic polity. The junta's rule by military decree and its wide use of discretionary power have appeared to weaken the state machinery. The increasing adoption of section 44 indicates the inaction and silent resistance among rational public officers.

In terms of state-business relations, the Pracharath model seems to convey different meanings for the military and the conglomerates. For the military junta, it only needs a brand-new catchword that distinguishes itself from the Thaksin governments in addition to being a platform to gain the public support of the business communities. In contrast, the Sino-Thai tycoons have joined the Pracharath schemes with their collective attempt to engage more in the rural economy. It has become a platform through which they could perform a leading role of Big Brother in nurturing and supervising small businesses towards a hierarchical mode of participation - an ideal form of economic interaction in the globalisation age wherein one cannot publicly express a preference for monopoly and anti-competitive practices.

\section{Acknowledgements}

The paper was originally presented at the 2017 AAS-in-ASIA conference in Seoul with the support from the National Research Foundation of Korea [Grant NRF-362-20081-B00018].

Prajak Kongkirati would like to thank Thongchai Winichakul and Michael Montesano for useful comments. This article has benefited greatly from support for the author's research on Prayuth government funded by the Direk Jayanama Research Center, Faculty of Political Science, Thammasat University. 
Veerayooth Kanchoochat would like to thank the support from the Emerging State Project [KAKENHI Grant No.25101004] of the Japan Society for the Promotion of Sciences (JSPS).

\section{References}

Acemoglu, Daron, and James Robinson. 2012. Why Nations Fail: The Origins of Power, Prosperity, and Poverty. London: Profile.

Asian Tribune. 2006. "Thai King endorses Gen. Surayud Chulanont, a former army chief for interim premiership,” October 2. Available at: http://www.asiantribune.com/ index.php?q=node/2252 (accessed on 5 June 2017).

BBC Thai. 2017. "Three years of the coup: Military officers controlling the state enterprise over the reform promise," June 5. Available at http://www.bbc.com/thai/thailand-40121632 (accessed 3 June 2017).

Boix, Carles, and Milan Svolik. 2013. "The foundations of limited authoritarian government: institutions and power-sharing in dictatorships." The Journal of Politics 75 (2): 300-316.

Brooker, Paul. 2009. Non-Democratic Regimes. Basingstoke: Palgrave Macmillan.

Connors, Michael. 2003. Democracy and National Identity in Thailand. London: Routledge.

Doner, Richard, and Anek Laothamatas. 1997. "Competitive clientelism and economic governance: The case of Thailand." In Business and the State in Developing Countries, edited by S. Maxfield and B. Schneider, 411-452. Ithaca, NY: Cornell University Press.

Gandhi, Jennifer, and Adam Przeworski. 2006. "Cooperation, cooptation and rebellion under dictatorships." Economics and Politics 18(1): 1-26.

Haberkorn, Tyrell. 2014. "Martial law and the criminalisation of thought in Thailand." The Asia-Pacific Journal: Japan Focus 12(40): 1-17.

Hall, Peter A., and David Soskice, eds. 2001. Varieties of Capitalism: The Institutional Foundations of Comparative Advantage. Oxford: Oxford University Press.

Harris, Joseph. 2015. "Who governs? Autonomous political networks as a challenge to power in Thailand." Journal of Contemporary Asia 45(1): 3-25.

Hicken, Allen, and Bangkok Pundit. 2016. "The effects of Thailand's proposed electoral system." Thai Data Points, 9 February. Available at: http://www.thaidatapoints.com/ project-updates/theeffectsofthailandsproposedelectoralsystembyallenhickenandbangkokpundit (accessed 1 June 2017).

iLaw. 2015. Report on the Exercise of Power under Section 44 of the Interim Constitution of Thailand, 18 November. https://ilaw.or.th/node/3938 (accessed 5 April 2018).

Isara News. 2016. "258 government officials and local administrators were suspended and removed by NCPO head," 31 July. Available at: https://www.isranews.org/investigative/investigate-news/item/48888-m44_48888oo.html (accessed 29 May 2017).

Jayasuriya, Kanishka, and Garry Rodan. 2007. "Beyond hybrid regimes: More participation, less contestation in Southeast Asia.” Journal of Democratisation 14(5): 773-794.

Kendall-Taylor, Andrea, and Erica Frantz. 2015. "Mimicking democracy to prolong autocracies." The Washington Quarterly 37(4): 71-84.

Kom Chad Luek. 2015. "Stop dragging your foot immediately," January 19.

Linz, Juan. 1970. “An authoritarian regime: Spain.” In Mass Politics, edited by Eric Allardt and Stein Rokkan, 251-283. New York: Free Press. 
Manager Online. 2014. "Threatening to remove civil servants to prevent foot dragging," December 20.

Marwaan Macan-Markar. 2017. “Thailand's junta could benefit from former PM’s escape.” Nikkei Asian Review, 28 August. Available at: https://asia.nikkei.com/PoliticsEconomy/Policy-Politics/Thailand-s-junta-could-benefit-from-former-PM-s-escape (accessed 18 September 2017).

Marshall, Monty G., and Donna Ramsey Marshall. 2015. Coup d'Etat Events, 1946-2014: Codebook. Available at: www.systemicpeace.org/inscr/CSPCoup-sCodebook2014. pdf (accessed 6 April 2018).

McCargo, Duncan. 2005. "Network monarchy and legitimacy crises in Thailand." The Pacific Review 18(4): 499-519.

Mérieau, Eugénie. 2016. “Thailand’s deep state, royal power and the constitutional court (1997-2015)." Journal of Contemporary Asia 46(3): 445-466.

Nanchanok, Wongsamuth. 2015. "Military mind games play out under strict insecurity." Bangkok Post, September 7. Available at: http://www.bangkokpost.com/print/ 708280/ (accessed 5 October 2017).

Nordlinger, Eric A. 1977. Soldiers in Politics: Military Coups and Governments. Englewood Cliffs, NJ: Prentice-Hall.

O'Donnell, Guillermo. 1979. Modernisation and Bureaucratic Authoritarianism: Studies in South American Politics. Berkeley, CA: University of California Press.

Powell, Jonathan, and Clayton Thyne. Coups d'etat, 1950 to Present. Available at: http:// www.uky.edu/ clthyn2/coup_data/home.htm (accessed 2 June 2017).

Prajak Kongkirati. 2012. "Thailand: The cultural politics of student resistance." In Student Activism in Asia: Between Protest and Powerlessness, edited by Meredith Weiss and Edward Aspinall, 229-258. Minneapolis: University of Minnesota Press.

Prajak Kongkirati. 2016. “Thailand's political future remains uncertain.” ISEAS Perspective 24. Available at: https://www.iseas.edu.sg/images/pdf/ISEAS_Perspective_2016_42. pdf (accessed 5 January 2017).

Puangthong Pawakapan. 2015. "Will Thailand's new constitution be a return to authoritarianism?” ISEAS Perspective 3. Singapore: ISEAS.

Puangthong Pawakapan. 2017. "The central role of Thailand's internal security operations command in the post-counter-insurgency period." ISEAS Trends in Southeast Asia 0219-3213. Available at: https://www.iseas.edu.sg/images/pdf/TRS17_17.pdf (accessed 20 April 2018).

Riggs, Fred W. 1966. Thailand: The Modernization of a Bureaucratic Polity. Honolulu, HI: East-West Center Press.

Sasiwan, Mokkhasen. 2016. "Fourth cabinet reshuffle introduces five newcomers." Khaosod English, 17 December. Available at: http://www.khaosodenglish.com/politics/2016/12/17/fourth-cabinet-reshuffle-introduces-five-newcomers (accessed on 30 May 2017).

Schneider, Ben Ross. 2013. Hierarchical Capitalism in Latin America: Business, Labor, and the Challenges of Equitable Development. New York: Cambridge University Press.

Thai PBS News. 2016. "Apiradee to officially demand 20,000 million baht compensation from six former officials,” 19 September. Available at: http://englishnews.thaipbs.or. th/apiradee-to-officially-demand-20000-million-baht-compensation-from-six-formerofficials (accessed 1 June 2017).

Thak Chaloemtiarana. 1979. Thailand: The Politics of Despotic Paternalism. Bangkok: Social Science Association of Thailand. 
Thanee, Chaiwat, and Pasuk Phongpaichit. 2008. "Rents and rent-seeking in the Thaksin era." In Thai Capital After the 1997 Crisis, edited by Pasuk Phongpaichit and C. Baker. Chiang Mai: Silkworm Books.

Thitinan Pongsudhirak. 2016. "Can we have 'Premocracy 2.0' in the 2010s?” Bangkok Post, 1 April. Available at http://www.bangkokpost.com/archive/can-we-have-premocracy-2-0-in-the-2010s-/917457 (accessed 2 June 2017).

Thorn Pitidol. 2016. "Redefining democratic discourse in Thailand's civil society." Journal of Contemporary Asia 46(3): 520-537.

Veerayooth Kanchoochat. 2016. "Reign-seeking and the rise of the unelected in Thailand." Journal of Contemporary Asia 46(3): 486-503.

Veerayooth Kanchoochat, and K. Hewison, eds. 2017. Military, Monarchy and Repression: Assessing Thailand's Authoritarian Turn. New York: Routledge.

Workpoint News. 2017. "Three years of NCPO and 152 orders of section 44," 22 May. Available at: http://workpointtv.com/news/32703 (accessed 30 May 2017). 